\title{
Impact of chimney on low emission
}

\author{
Krzysztof Drożdżol ${ }^{1, *}$, Pawet Jarzyński ${ }^{2}$ \\ ${ }^{1}$ Opole University of Technology, Faculty of Civil Engineering and Architecture \\ Katowicka 48 Street, 45-061 Opole, Poland \\ ${ }^{2}$ Jawar Sp z o.o., Sońska 89 Street, 06-400 Ciechanów
}

\begin{abstract}
The air pollution caused by operation of heating devices using solid fuels is a significant problem in Poland and neighbour countries. The pollution level is so high, that some voivodships impose anti-smog acts, banning the use of heating devices which do not meet requirements of the $5^{\text {th }}$ class according to EN 303-5. By 2023 the ban is going to be imposed nationwide. In order to improve the air quality, heating devices' producers take constant measures to improve their products. It is recently expected that those devices meet the strict 5 th class emission requirements, as well as other directives' requirements, including the Ecodesign Directive 2009/125/EC. However, the emission results achieved during initial test of heating devices in laboratory may be much worse during operation in real operating conditions. The research included tests proving that the chimney system applied to a heating device might influence the emission of particles exhausted with the smoke. The tests have been performed in real-life conditions, on a test rig that was prepared for this purpose. The research has proved that emission values of heating devices will change, chimney system applied.
\end{abstract}

\section{Introduction}

The use of fuel combusting devices entails the problem of air pollution. The topic of pollution with $\mathrm{CO}, \mathrm{CO}_{2}, \mathrm{SO}_{2}, \mathrm{NO}_{\mathrm{x}}, \mathrm{PaHs}$, ecotoxic elements etc. as well as with dust is a current problem worldwide. It is particularly visible in the winter period. According to the statistics, Poland is located on $24^{\text {th }}$ place in respect of the amount of emission of dust PM2,5 [1]. European Environment Agency informs that almost 43,000 people die prematurely each year due to air pollution. The authorities of European Union and Poland do not remain indifferent to the presented problem of air pollution. EU directives, aiming at the improvement of the quality of air are being continuously introduced, locally the antismog regulations and resolutions are adopted [2-6], indicating among others type of heating devices and fuels allowed for sales and use. Simultaneously, European Commission conducts the investigation regarding the breach of EU law in relation to poor quality of air in Czech Republic, Germany, Spain, France, Italy, Hungary, Rumania, Slovakia and Great Britain, however Poland has already been obliged to solve this problem before the Court of Justice of European Commission [7]. High concentration of pollutants in Poland resulted in

\footnotetext{
* Corresponding author: k.drozdzol@po.opole.pl
} 
creation of social movement towards reduction of the emission of pollutants. Apart from social campaigns, weather forecasts have been enriched with the information related to concentration of dust, the cities install special points measuring concentration of air dustiness. The measurements from those points can be followed online or with the use of applications on mobile devices. The problem has become so common that antismog masks showcased and offered for sales in clothing stores became a new trend of fashion. Together with the increase of social activity in favour of improvement of air quality, one can observe intensification of the amount of scientific research related to this topic. The results of research conducted by scientific units contribute to developing and implementing solutions reducing the amount of pollutants from transportation, heating of buildings and industrial processes. The fact that the air quality deteriorates significantly in the winter period in the countries where heating buildings is required, results from the use of heating devices. Energy consumption of the building, type and quality of the fuel used and heating device, as well as the chimney which is used to discharge the flue gas, directly influences the increase of the emission of pollutants and flue gas to the atmosphere. Appropriate insulation of the building results in the reduction of heat loses and reduction of the amount of fuel used [8]. There are many research concerning fuels and determination of harmful substances created and released during fuel combustion in furnaces, as described in the articles, [9-12]. This information is very important in the context of developing new solutions in heating devices and fuels, which allows to increase the energy efficiency and reduce the emission of harmful products created during combustion [13-14]. Such research allows for continuous improvement of fuels and heating devices. It turns out that chimney systems responsible for discharging gas and flue gases from the buildings play equally significant role in relation to the discussed problem. As it is described in the articles [15-17]. This is due to the fact that their construction has direct impact on the size of chimney loss (thermal energy discharged through the chimney), and parameters of gases flowing through the hearth of the furnace, and this in turn has direct influence on the processes taking place during combustion. In practice, one may very often encounter the situations in which modern heating devices are connected to the chimneys with incorrect diameters. The chimney's sections contract as a result of deposition of dust and soot. The information obtained as a result of research described in the article [18] is very important in this respect. They present the role of chimney draught in relation to the processes occurring in combustion chamber of biomass fuelled boiler. The draught was regulated through changing the diameter of the chimney duct. The researchers proved that the chimney draught has an impact on the amount air fed to the hearth and in consequence, the amount of carbon monoxide produced and the temperature of flue gas. The surplus of air cools down the combustion chamber and results further in the reduction of efficiency of the device. After reduction of the chimney's diameter, which resulted in the increase of the coefficient of friction losses in the chimney, reduction in the production of carbon monoxide was observed. The quantity of air mass sucked into the heating device was also reduced and therefore its efficiency improved. The described problem is often encountered in real-life, where heating devices are characterised with excessive chimney draught.

The subject matter article describes the research related to the influence of the type and diameter of the chimney on the emission of pollutants to the atmosphere with particular attention on solid particles. The study of literature did not found research related to this type of issue.

\section{Experimental}

The influence of chimney's diameter and type of its fittings on the emission of flue gases was assessed based on the tests. Examination post, consisting of the chimneys with three 
different diameters $(\varnothing 120, \varnothing 160, \varnothing 200)$ was created for this purpose. The models simulated respectively: $\varnothing 120$ - chimney with too small diameter, $\varnothing 160$ - chimney with an optimum diameter, selected according to producers recommendations, Ø200 - chimney with too big diameter. Fourth chimney with an optimal diameter was additionally equipped with an air space, which was used to feed the air to the hearth of the furnace with closed combustion chamber. The chimneys were connected to two different stoves - one with open combustion chamber; the other one with closed combustion chamber and afterburning. Detailed information on installation is presented in point 3.1.

In the framework of the research, the range of measurements were conducted to determine the composition of flue gas, discharged through chimney ducts. The concentrations of the following elements in the flue gas were measured:: oxygen $\left(\mathrm{O}_{2}\right)[\%]$, carbon dioxide $\left(\mathrm{CO}_{2}\right)[\%]$ and monoxide $(\mathrm{CO})[\mathrm{ppm}]$. Moreover, the concentration of dust was estimated in a simplified way by determining soot count. The "soot count" is a level on the Bacharach smoke scale, which was developed as a measure of a soot - forming potential of flue gases. The scale identifies different soot levels - the higher level the more soot (dust) is being produced. The measurements were registered depending on the used chimney and hearth. Birch - was the wood burned in the furnaces, during the research. The moisture content of each chunk of wood was measured before the fuel was placed in the hearth. The moisture content of wood ranged from $12 \div 20 \%$. The wood was previously appropriately seasoned in order to pre-dry. During research, ambient air parameters were also measured: temperature $\left[{ }^{\circ} \mathrm{C}\right]$, speed of wind $[\mathrm{m} / \mathrm{s}]$, humidity $[\%]$, carbon dioxide concentration $[\mathrm{ppm}]$, carbon monoxide concentration $[\mathrm{ppm}]$, pressure $[\mathrm{hPa}]$. During the measurements the following parameters were additionally checked: flue gas temperature at chimney outlet $\left[{ }^{\circ} \mathrm{C}\right]$, temperature of flue gas in the chimney $\left[{ }^{\circ} \mathrm{C}\right]$, (in the place of measurement and in the area of the outlet), temperature of the air fed into the hearth $\left[{ }^{\circ} \mathrm{C}\right]$, flue gas pressure $[\mathrm{Pa}]$, flue gas flow rate $\left[\mathrm{m}^{3} / \mathrm{s}\right]$, air flow rate $\left[\mathrm{m}^{3} / \mathrm{s}\right]$ (for the chimney with the air jacket). The examination of the above mentioned parameters was conducted in the following stages:

Stage I: (basic): this stage used typical furnace, feeding the air for combustion from the room and without application of the secondary afterburning system. These tests were performed after connecting it to the chimney of the diameter of $\varnothing 120 \mathrm{~mm}, \varnothing 160 \mathrm{~mm}$, $\varnothing 200 \mathrm{~mm}$.

Stage II: during this stage, the examination of the above mentioned parameters was conducted with the use of a furnace with so called secondary afterburning (clean combustion), and supply of air for combustion from the outside directly to the closed combustion chamber. Tested chimneys were of the same diameter as in stage I.

Stage III: covered examination of the chimney with the diameter of $\varnothing 160 \mathrm{~mm}$ as in Stage II with the supply of preheated air for combustion through chimney air duct.

Stage IV: covered the examinations like Stage III with the use of chimney draught regulator.

Stage $\mathbf{V}$ : covered the analysis of the flue gas and additionally the amount of dust released to the atmosphere. The research was conducted with reference method [19]. 


\section{Description of Research}

\subsection{Examination post}

\subsubsection{Chimneys}

The examination post (fig. 1,2), consisting of four chimney systems was designed for the purpose of the research. Ceramic-concrete chimneys, used in the research, were constructed and delivered by the producer, the company Jawar Sp. z o.o. The used systems consisted respectively of: kermasite hollow brick, insulation made of mineral wool and a pipe made of isostatic ceramics. Chimney's diameters measured respectively $120 \mathrm{~mm}, 160 \mathrm{~mm}, 200$ $\mathrm{mm}$.

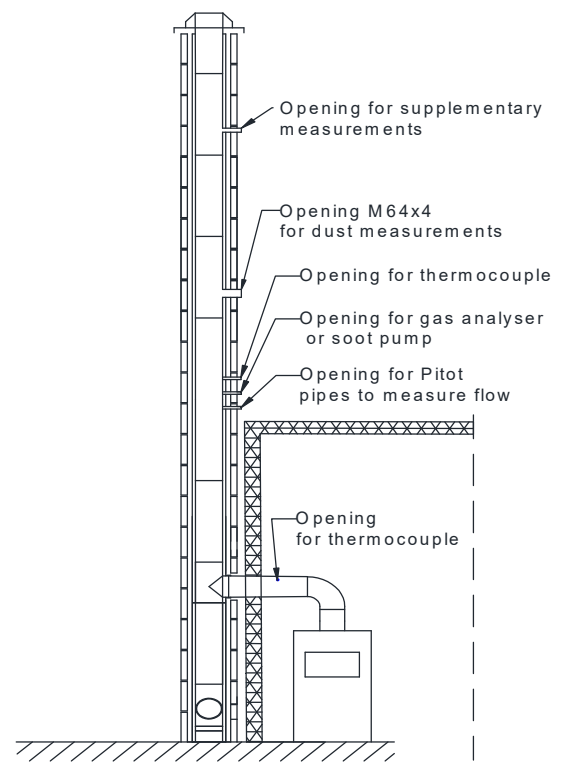

Fig. 1. Scheme of the examination post indicating the location of measurement spots

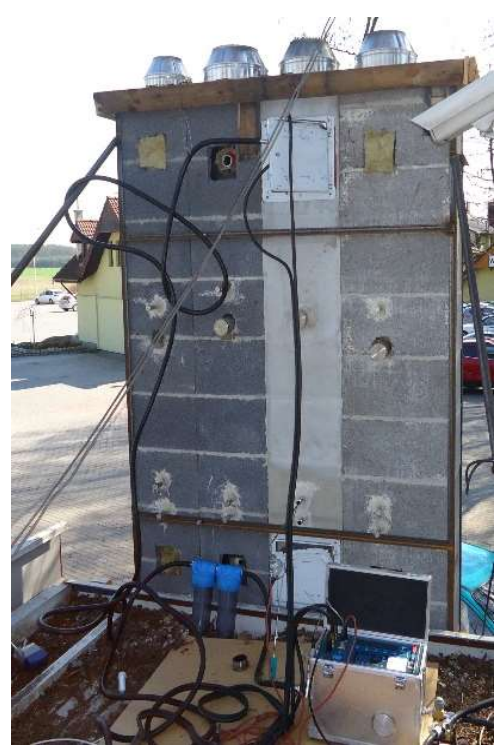

Fig. 2. Examination post

The fourth system consisted of the same elements as in the above schemes, however additionally an air space was placed between the insulation and hollow bricks layer, which fed the air to the hearth (hereinafter this system will be referred to as Jawar NORD chimney). During the research in stages IV and V, the chimney system was additionally fitted with mechanical chimney draught regulator. Chimney systems were characterised with thermal resistance as presented in the table below:

Table 1. Thermal resistance of the materials used to create chimney systems

\begin{tabular}{|c|c|c|c|c|}
\hline \multirow[b]{2}{*}{$\begin{array}{l}\text { Diameter and } \\
\text { chimney type }\end{array}$} & \multicolumn{4}{|c|}{ Thermal resistance $\left[\mathrm{m}^{2} \mathrm{~K} / \mathrm{W}\right]$} \\
\hline & $\begin{array}{l}15 \text { mm thick ceramic } \\
\text { chimney pipe }\end{array}$ & $\begin{array}{l}\text { Insulation made } \\
\text { of mineral wool }\end{array}$ & Air space & $\begin{array}{c}\text { Hollow } \\
\text { bricks }\end{array}$ \\
\hline $120 \mathrm{~mm}$ & 0.1 & 1.16 & - & 1.03 \\
\hline $160 \mathrm{~mm}$ & 0.1 & 0.98 & - & 0.91 \\
\hline $200 \mathrm{~mm}$ & 0.1 & 0.69 & - & 0.68 \\
\hline $160 \mathrm{~mm}$ (NORD) & 0.1 & 0.98 & $\sim 0.1$ & $\sim 0.8$ \\
\hline
\end{tabular}




\subsubsection{Furnaces}

Two types of furnaces were used in the research:

1) Furnace Ackerman P5, the air for combustion is fed from the room, power of $7.5 \mathrm{~kW}$, efficiency of $80.3 \%$ and minimum required chimney draught of $12 \mathrm{~Pa}$ [3],

2) Furnaces prototype (no detailed information on parameters), the air for combustion is fed directly to the furnace from the outside, fitted with a deflector, secondary afterburning system, power of around $8 \mathrm{~kW}$ and efficiency around $85 \%$ [3].

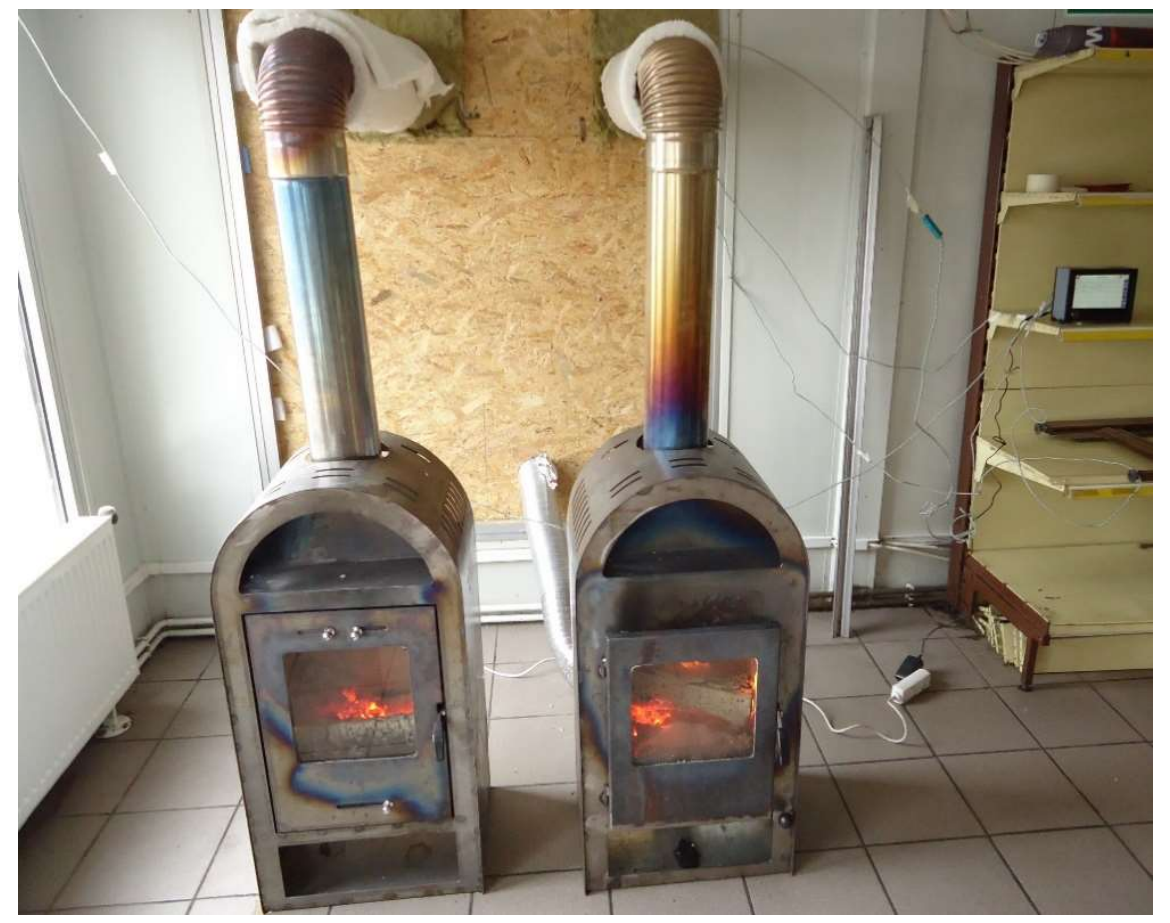

Fig. 3. Models of the furnaces used in the research (examination post inside the building)

\subsection{Course of research}

The examination post was constructed based on the guidelines described in the norm" [20]. The research was conducted following the stages presented in point 3 . The measurements were preceded with conditioning in the form of heating up the installation. The time of conditioning of the installation before proceeding with the research, each time lasted over 2 hours. As far as possible, the measurements were conducted in similar weather condition, meaning absence of precipitation, absence of wind or weak wind $(<5 \mathrm{~m} / \mathrm{s})$, absence of fog, similar air temperature (in the range of $10 \div 20^{\circ} \mathrm{C}$ ). Amount of fuel, which was used for each stage of research was weighted. Each time the fuel was fed to the furnace in similar amount. All measurements were performed at least twice. In case of assuming that external factors could influence the quality of research, the measurements were repeated several times in order to reduce the probability of error occurrence. Moreover, each examination was conducted on two different dates. 


\subsection{Results and discussion}

The mean value of the concentration of $\mathrm{CO}, \mathrm{CO}_{2}, \mathrm{O}_{2}$, soot count (determined according to Bacharach's scale) and the chimney draught obtained from the measurements taken during stage I of research are presented in the form of diagrams Fig. 4 and 5. The readouts for the same parameters obtained during the examinations in stages II $\div \mathrm{IV}$ are collated in Fig. 6, 7.

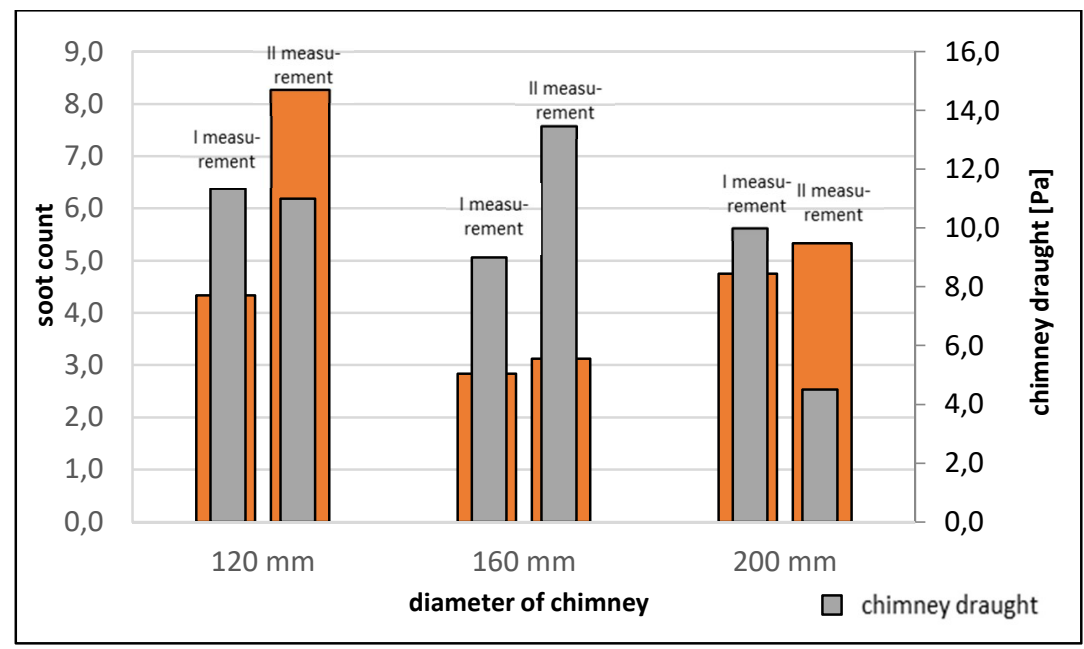

Fig. 4. Averaged values of soot counts, and chimney draught recorded during the implementation of Stage I of the tests

The results of research presented in the diagrams show that the emission of $\mathrm{CO}_{2}$ has a tendency to increase together with the increase of the value of the pressure of the flue gas flowing through the chimney. The concentration of $\mathrm{CO}$ in flue gas discharged through the chimney without air layer increased together with the increase of the chimney's diameter. Those dependencies were observed regardless of the type of hearth used, meaning traditional or with so called clean combustion technique.

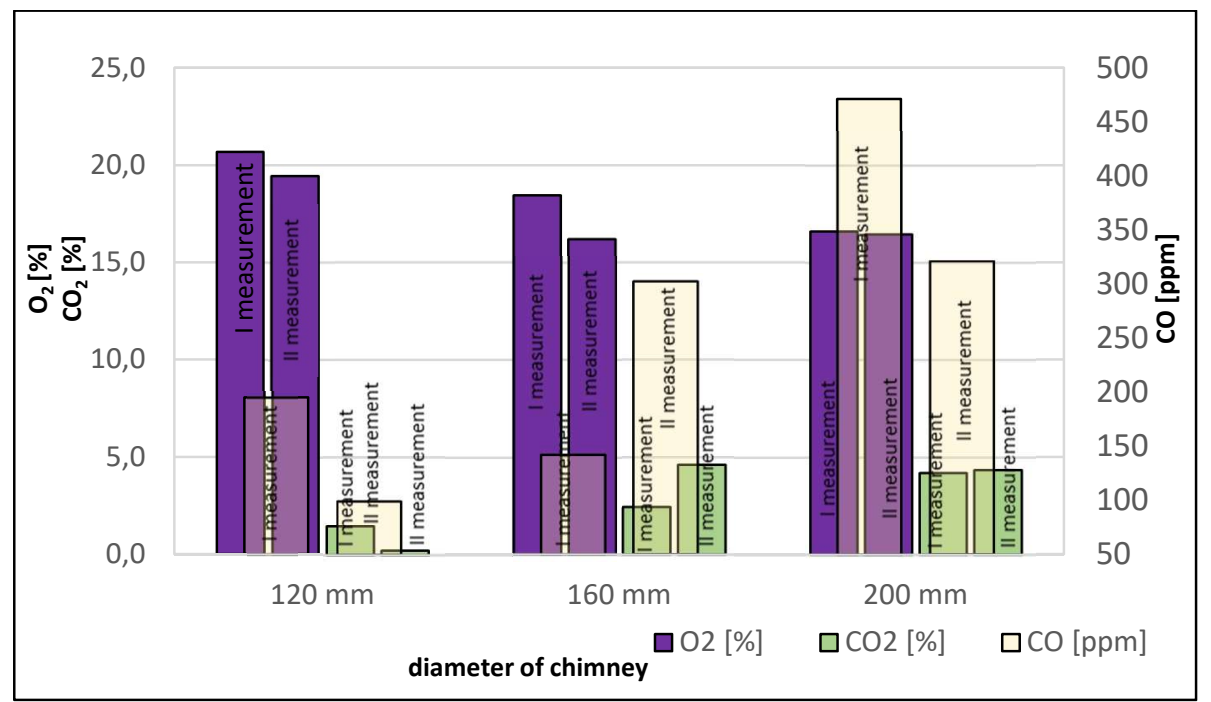

Fig. 5. Summary of $\mathrm{CO}, \mathrm{CO}_{2}$ and $\mathrm{O}_{2}$ concentrations in flue gas during study implementation in Stage I 
Conducted research including measuring the concentrations of dusts and pressures shows that there is no dependency between those values. The analysis of the diagram presented in Fig. $4 \div 7$ shows that the use of secondary afterburning in the furnaces does not guarantee the reduction of the amount of dusts emission. This emission increases, when the furnace is connected to the chimney system with incorrect dimensions or without appropriate equipment.

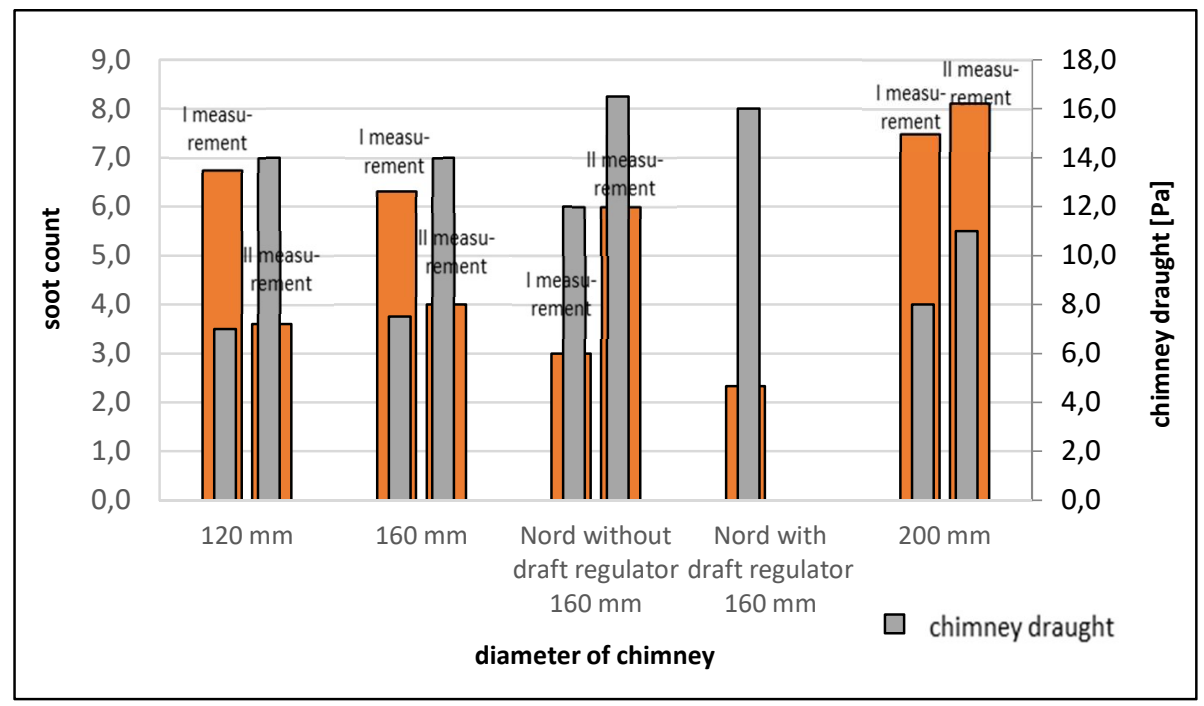

Fig. 6. Averaged values of concentrations of flue gas composition recorded during test implementation in Stages II, III, IV

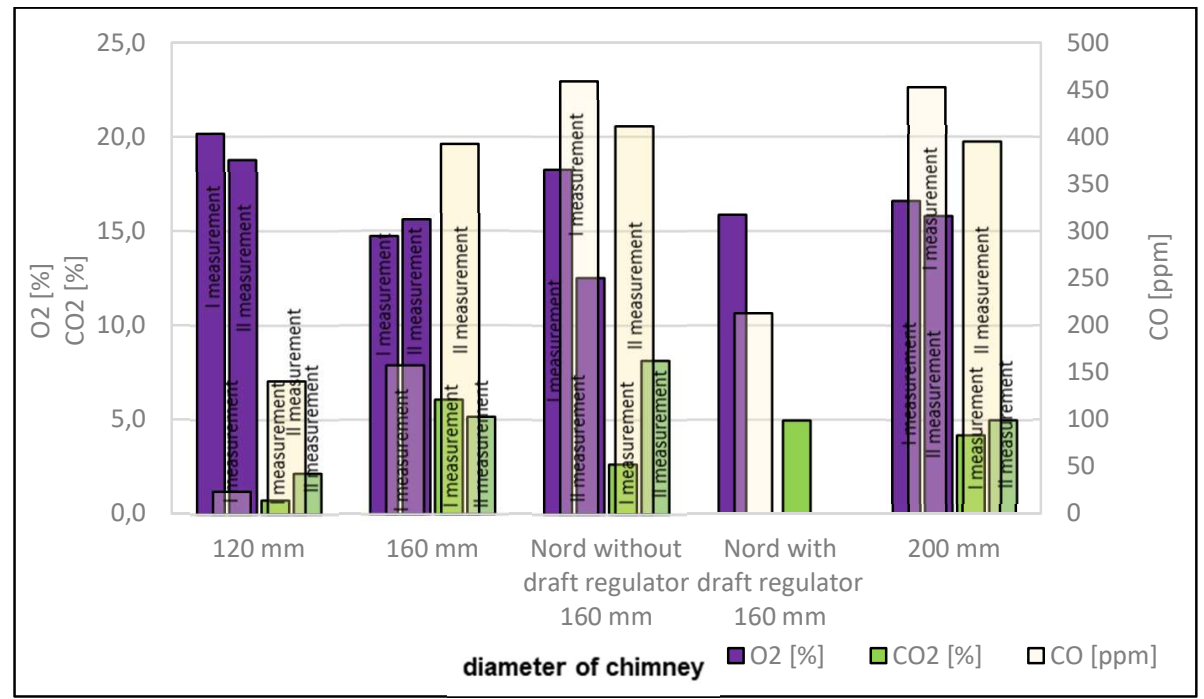

Fig. 7. Averaged values of soot counts recorded during test implementation in Stages II, III, IV

Comparison of the diagrams 4 and 7 shows that the traditional furnace when connected to the optimally selected chimney system of the diameter of $\varnothing 160$ emitted smaller amount of pollutants than the furnace with clean combustion. The furnace equipped with deflectors, flue gas combustion and closed combustion chamber reaches better emission parameters in comparison with the traditional furnace. However, this took place only after ensuring 
appropriate quality and quantity of air feed for combustion. Feeding the air for combustion through the NORD type chimney system equipped with draught regulator resulted in the decrease of soot count even by 6 values in Bacharach's 10 degree scale. The analysis of dust was also performed with reference method according to PN-EN 15259:2011 [19] and PN-Z-04030-7:1994 [20]. The amount of dusts emitted from the subject matter installation was determined during the research. During the first measurement, the value of emission was $56.35 \mathrm{mg} / \mathrm{m}_{\mathrm{u}}{ }^{3}$, and during the second: $65.50 \mathrm{mg} / \mathrm{m}_{\mathrm{u}}{ }^{3}$. This shows that the heating device reached 4 emission class in real-life conditions according to EN-303-5:2012 [21].

\section{Summary and conclusions}

The problem of air pollution coming from low emission constitutes a grave danger for health and life of people living in the affected area. This is backed up by medical statistics presented in the introduction and at https://polskialarmsmogowy.pl [1]. The statistics show that smog contributed to a large number of diseases and deaths.

Currently, the quality of the air in Poland is very poor, this is the reason why subsequent repair programs should be immediately continued and implemented. The implemented programs concern mainly the control of used fuels, subsidies for boiler replacement and thermal modernization of buildings. The conducted research, described in the subject matter article, show that in order to obtain the anticipated effect of reduction of the emission it is not enough to only replace the heating device. It is indispensable to expand the scope of action by adjusting the chimney to the heating device and its proper use. The research showed that the role of the way in which the air is feed to combustion area is no less significant. This is justified by the conclusions which can be drawn from the research:

1. The selection of the chimney has an influence on the concentration of dusts in the flue gas discharged through the chimney. In the case of too small and too large diameters of the chimney duct the soot count increase regardless of the type of furnace used during the research.

2. Feeding preheated air through the chimney duct to the hearth allows to reduce the soot count. Moreover, the use of draught regulator significantly reduces the emission of dusts to the atmosphere.

3. The emission of $\mathrm{CO}_{2}$ has a tendency to increase together with the increase of the value of the pressure of the flue gas flowing through the chimney.

4. In the typical chimney systems without additional solutions, the emission of $\mathrm{CO}$ increases together with the increase of the diameter of the chimney, regardless of the type of hearth used.

5. The use of secondary afterburning in the furnaces does not guarantee the reduction of soot emission with the use of incorrect chimney systems.

The research was co-financed by: Pipeeksperten AS (Norway), Jawar Sp z o.o., Cech Kominiarzy Polskich (Polish Chimneys Guild), Ackerman S.A.

\section{References}

1. https://polskialarmsmogowy.pl (data of visit 22 January 2018)

2. Directive 2008/50/EC of the European Parliament and the Council of 21 May 2008 (CAFE).

3. Directive 2009/125/EC of the European Parliament and the Council, (Ecodesign)

4. Act of 5 June 1998 on the government of the voivodship (i.e. Journal of Law of 2016 item 486 as amended) 
5. Act of 27 April 2001 - Law on environmental protection (i.e. Journal of Law of 2007, item 519 as amended)

6. Resolution of Opole Regional Assembly no. XXXII/367/2017 of 26 September 2017 on introducing within the area of the Opole voivodeship limitations regarding the use of installations in which flue combustion takes place

7. http://forsal.pl/artykuly/1106298,trybunal-ue-polska-zlamala-unijne-przepisydotyczace-jakosci-powietrza.html (date of visit 23.02.2018)

8. K. Kubica: Efektywne i przyjazne środowisku źródła ciepła - ograniczenie niskiej emisji. Katowice: Polski Klub Ekologiczny Okręg Górnośląski, 2007

9. E.J.S. Mitchell, A.R. Lea-Langton, J.M. Jones, A. Williams, P. Layden, R. Johnson., Fuel Processing Technology., 142, p: 115-123, (2016)

10. P. Lachman, InstalReporter, 2013(01), p:29-30. (2013)

11. J. Kjällstrand, M. Olsson., Biomass and Bioenergy, 27, p: 557-561, (2004)

12. D. Makowska, F. Wierońska, T. Dziok, A. Strugała., Polityka Energetyczna., 20(4), p: 89-102, (2016)

13. R. Junga, P. Chudy, J. Pospolita., Measurement, 971, p: 86-195, (2017)

14. R. Junga, M. Wzorek, M. Kaszubska., E3S Web of Conferences 19, 01009, (2017)

15. P. Jarzyński, K. Drożdżol.: wyd. Wojewódzki Cech Kominiarzy w Opolu., seria Monografie, s. 59-72, (2014)

16. K. Drożdżol., Inżynier budownictwa, 147, p: 101-104, (2016)

17. K. Drożdżol., Inżynieria i Budownictwo, 11/2016, p: 616-618, (2016)

18. J. Prapas, M.E. Baumgardner, A.J. Marchese, B. Willson, M. DeFoort., 23, Energy for Sustainable Development, p: 286-293, (2014)

19. Polish standard - PN-EN 15259: 2011, Jakość powietrza - pomiary emisji ze źródeł stacjonarnych - wymagania dotyczące odcinków pomiarowych i miejsc pomiaru, celu i planu pomiaru oraz sprawozdania $\mathrm{z}$ pomiaru

20. Polish standard - PN-Z-04030-7:1994, Ochrona czystości powietrza - Badania zawartości pyłu - Pomiar stężenia i strumienia masy pyłu w gazach odlotowych metodą grawimetryczną

21. Europe strandard - EN 303-5:2012 Heating boilers for solid fuels, manually and automatically stoked, nominal heat output of up to $500 \mathrm{~kW}$ - Terminology, requirements, testing and marking 